\title{
Assessment and mapping of snow avalanche risk in Russia
}

\author{
Yuri SELIVERSTOV, Tatiana GLAZOVSKAYA, Alexander SHNYPARKOV, Yana VILCHEK, \\ Ksenia SERGEEVA, Alexei MARTYNOV
}

\author{
Research Laboratory of Snow Avalanches and Debris Flows, Faculty of Geography, M. V. Lomonosov Moscow State University, \\ Vorobievy Gory, 119991 Moscow, Russia \\ E-mail: yus5@yandex.ru
}

\begin{abstract}
The term 'risk' can be defined as the probability of unfavourable consequences or negative effects. Risk can be expressed by means of various indices, such as collective or social risk (possible number of dead), individual risk (probability of a person's death within a certain territory during 1 year), probability of losses, etc. This paper is a case study of the small-scale assessment and mapping of individual avalanche risk focused on the two regions of Russia with the highest levels of avalanche activity: the northern Caucasus and the mountainous parts of Sakhalin island. The basic indices applied for individual avalanche risk estimation are: recurrence interval of avalanches (avalanche frequency), percentage of the whole investigated territory that is occupied by avalanche-prone areas, duration of avalanche danger period, probability of a person's stay in an avalanche-prone area during 1 day (24 hours) and during 1 year, total population of the area and its density. The results of individual avalanche risk assessment, undertaken for the territory of Russia as a whole, show that its values generally do not exceed the admissible level (from $1 \times 10^{-6}$ to $1 \times 10^{-4}$ ). However, some areas of the northern Caucasus, including famous alpine skiing resorts (Krasnaya Poliana, Dombai, the Mount Elbrus region, etc.), and of Sakhalin, including the environs of towns (Kholmsk, Nevel'sk) and other smaller human settlements, are characterized by an unacceptable level of risk. In the aggregate, areas with an unacceptable $\left(>1 \times \mathbf{1 0}^{-4}\right)$ level of individual avalanche risk comprise about $7 \%$ of the whole avalancheprone territory of the northern Caucasus, those with an admissible level comprise $52 \%$ and those with an acceptable level $\left(<1 \times 10^{-6}\right) 41 \%$. The corresponding values for Sakhalin are $0.1 \%, 14.8 \%$ and $85.1 \%$.
\end{abstract}

\section{INTRODUCTION}

During the last 25 years scientists and experts all over the world have paid serious consideration to the problem of avalanche risk assessment. Basic principles and conclusions reached in the process of such evaluation can be expressed with the help of the following indices: social (individual and collective risks), economic (possible annual losses, expected percentage of destroyed buildings and other constructions, probability of forced stoppage on railroads and highways) and ecological (possible ecosystem disturbances, probability of death among unique representatives of rare and valuable plant and animal species, etc.). The most commonly used index is individual avalanche risk, which is usually defined as the probability of a person's death being caused by the impact of a snow avalanche within a certain area during 1 year. Most investigations conducted on this topic are represented by large-scale assessments of individual avalanche risk (e.g. Bohnenblust and Troxler, 1987; Andreev and others, 1997; Wilhelm, 1998; Jónasson and others, 1999; Keylock and others, 1999; Kazakov, 2000; Margreth and others, 2002; Arnalds and others, 2004; Bell and Glade, 2004; Zischg and others, 2005; Keiler and others, 2006). A review of such publications shows that existing methodologies and techniques of individual avalanche risk assessment and calculation are based mainly on careful consideration of snow avalanche characteristics and analysis of the degrees of a person's vulnerability to avalanches. The index of vulnerability may vary depending on a person's location in a building (in which case it is necessary to take into account the building's type and basic engineering features), in a car or in open space. All formulae proposed for individual risk estimation include parameters which are practically impossible to define in order to serve the purpose of small-scale assessment, or the assessment of uncertainty might be extremely high. In this context, the development and adjustment of methodologies and techniques for avalanche risk assessment and mapping, given that large areas of Russia are avalanche-prone, are of vital importance for solving both theoretical and applied tasks. The present paper is devoted to the analysis of corresponding problems using the example of two regions with relatively developed economic and infrastructure systems which can be classified as the most avalanche-prone areas of the country: the northern Caucasus and Sakhalin island.

\section{BACKGROUND}

Avalanche-prone areas include all mountain lands where a combination of two factors exists: (1) slope angles are $17^{\circ}$ or more; and (2) snow cover of $30 \mathrm{~cm}$ depth or more is in steady state for 1 month or more (Institut Geografii RAN, 1997). In Russia, avalanche-prone areas occupy a total of $3.1 \times$ $10^{6} \mathrm{~km}^{2}$, which is $18 \%$ of the total territory. A further $4.8 \%$ of the country may be considered as potential hazard zones, where under present natural conditions no avalanching takes place but, due to possible increasing snowiness or reduction of forestation, avalanche formation can start. Many large mountain systems, such as the Khibiny mountains, the northern Caucasus, the Urals, the Altai, the Sayan, the Lake Baikal and trans-Baikal regions, the Putorana plateau, the Byrranga mountains and the mountainous areas of the Far East, including Kamchatka, Sakhalin and the Kurile Islands, belong to avalanche-prone territories. The highest values of avalanche fatality rate and economic damage are registered 


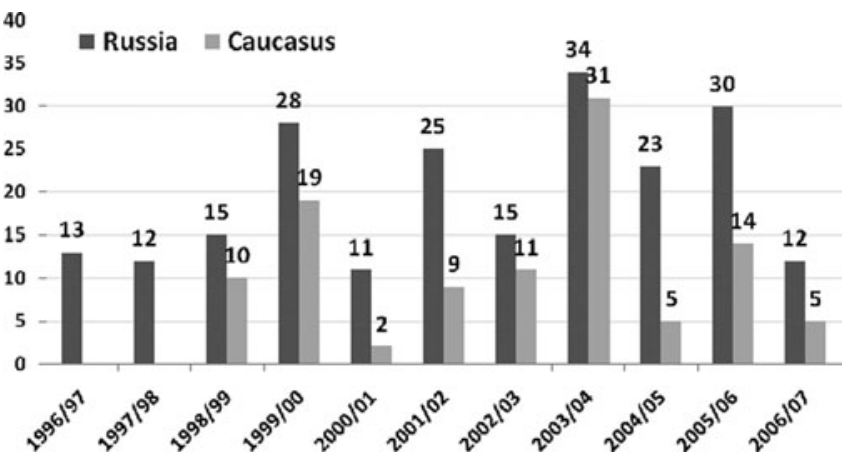

Fig. 1. Annual (1 October-30 September) avalanche fatalities in Russia as a whole and in the northern Caucasus, for the period 1996-2007.

in the northern Caucasus and Sakhalin. We estimate that more than 6200000 people live in avalanche-prone areas of Russia. The average population density in areas characterized by the probability of avalanche impact is less than 2 persons $\mathrm{km}^{-2}$; in the northern Caucasus this index rises to 22 persons $\mathrm{km}^{-2}$. We have collected reliable information about 218 victims of snow avalanches in Russia, recorded during the period 1996-2007 (Fig. 1). Avalanche catastrophes have also occurred regularly in Russia in the more remote past. In the mid-20th century, fatalities occurred mostly among settlement dwellers when avalanches caught them in their houses and other buildings. For example, on 5 December 1935 two avalanches from Yukspor mountain in the Khibiny mountains caused 88 fatalities and substantial damage in a miners' township. On 9 February 1945 an avalanche destroyed several houses in the township of Middle Medvezhka, Sakhalin, and killed 169 people. In the Seymchan river basin, located in the Magadan region, an avalanche on 28 March 1951 caused many deaths and totally destroyed the Gulag penitentiary camp. High levels of fatalities have also been typical among those who travel by mountain roads. In January-February 1993, 200 avalanches struck the trans-Caucasian highway in the Republic of North Ossetia-Alania; 54 car drivers and passengers were killed as a result of avalanche deposits obstructing the road. In general, the trans-Caucasian highway is the most avalancheprone road in Russia (Fig. 2). Avalanche fatalities occur regularly among the local population in mountain settlements and their environs. They are also quite common events in mountain recreation, tourism and active leisure zones, where there is a high incidence of deaths of skiers, snowboarders and climbers (Fig. 3).

Avalanche activity is also economically damaging. At the end of the 1980s the annual overall material losses in the USSR caused by snow avalanches were estimated at US\$10-15m (Kurbatova and others, 1997). In recent years, considerable damage has been recorded in Dagestan, Kabardino-Balkaria and Karachayevo-Cherkessia. At the beginning of April 2003, six avalanches destroyed several public buildings in Tsakhur, a settlement in Dagestan. The preliminary estimate of the cost of the damage was more than US\$300,000. Following a serious avalanche accident in the township of Terskol, northern Caucasus, on 2 March 2005, about US\$500,000 was spent on reconstructing an electric power station. Destruction of avalanche protection structures on roads and railways in various mountain regions of the country also entails large expenditures.

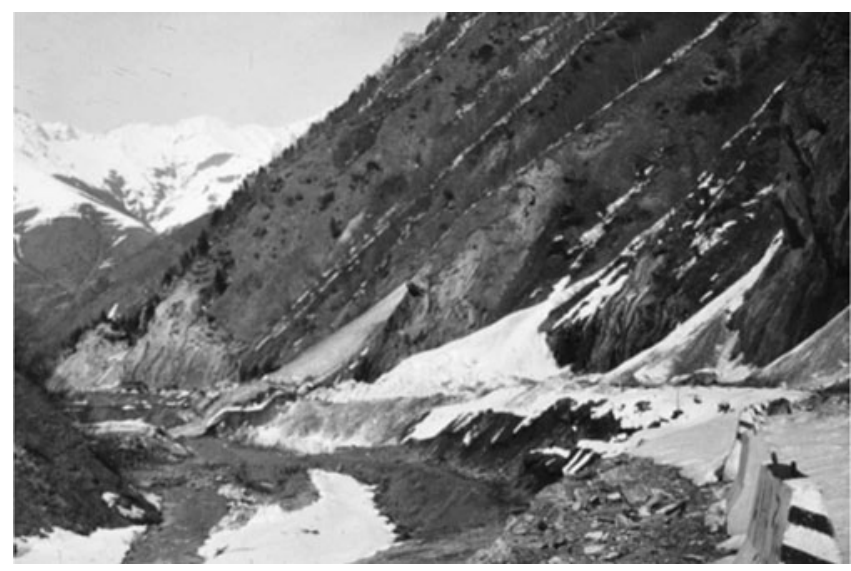

Fig. 2. Avalanche deposits on the trans-Caucasian highway in 1987. Photo: S. Sozayev.

Thus, snow avalanches are a real and undoubted menace for people living, working and holidaying in many mountain areas of Russia. The most fatalities and the most serious economic damage are now registered in the northern Caucasus. Catastrophic avalanches followed by large numbers of deaths also often occur in Sakhalin.

\section{METHODS}

Integrated investigations, aimed at developing methodologies and techniques of risk assessment and possible damage evaluation connected with various dangerous natural processes and phenomena, have long been conducted in the Research Laboratory of Snow Avalanches and Debris Flows at M.V. Lomonosov Moscow State University (MSU). These methodologies and techniques can be used in different scales and allow risk estimations to be obtained for the local population, migrating people and tourists, as well as for many categories of protected systems (roads, railways, means of transportation, etc.). In this paper, methods of collective and individual avalanche risk assessment for large mountain regions are presented. They are elaborated on the basis of the methodology applied for karst risk evaluation as suggested by Yolkin (2004).

Avalanche risk can be treated as the probability of various losses occurring due to avalanche impact during a specific period of time in a certain area (Miagkov, 1995). These losses can be expressed as different indices:

annual number of dead;

probability of the death of an individual belonging to a particular group of people living within a given area permanently or staying there temporarily;

probable damage magnitude;

probable proportion of destroyed and damaged buildings and other constructions;

probable cost of disruption to transportation systems as a result of avalanche activity.

The possible damage is evaluated taking into account various social and economic parameters, as well as a number of avalanche activity characteristics which determine the probability of losses (Molotkov, 1992; Seliverstov, 1992). Thematic maps from the 'World Atlas of Snow and Ice 
Resources' (Institut Geografii RAN, 1997) compiled by researchers of the MSU Faculty of Geography were used as the principal source of snow and avalanche information. Calculations were made with the help of GIS (Geographic Information Systems) Maplnfo. All areas under investigation were divided into exact squares (gridcells), each side of which equalled $3 \mathrm{~km}$ on the map applied as a basis for estimation.

To obtain the values of avalanche risk indices for all gridcells, subsequent calculations of the following parameters were made:

\section{Population vulnerability in time $\left(V_{t}\right)$}

This index defines the duration of stay (time of exposure) of an individual in avalanche hazard areas during the average day and year. It is estimated as a function of the duration of stay of an individual and their possible location within the dangerous territory:

$$
V_{\mathrm{t}}=\frac{t_{\mathrm{d}}}{24} \frac{t_{\mathrm{y}}}{365}
$$

where $t_{\mathrm{d}}$ is the average duration of stay of a typical local individual within the dangerous territory during 1 day and $t_{y}$ is the average duration of stay of a typical local individual within the dangerous territory during 1 year. The values of $t_{\mathrm{d}}$ were estimated on the basis of expert evaluation and generalization mainly due to the presence or absence of human settlements and roads in areas under investigation. In this project the following values are applied:

if there are no roads and human settlements, $t_{\mathrm{d}}$ is equal to $1 \mathrm{~s}$;

if there are some roads, $t_{\mathrm{d}}$ is equal to $1 \mathrm{~min}$;

if there are any human settlements, $t_{\mathrm{d}}$ is equal to 1 hour.

The values of $t_{y}$ correspond to the annual duration of avalanche danger period (the number of days). The annual duration of the avalanche danger period is the average number of days with snow-cover depth $30 \mathrm{~cm}$ and more.

\section{Population vulnerability in space $\left(V_{\mathrm{s}}\right)$}

This index is a function of the degree to which a territory is exposed to the impact of snow avalanches:

$$
V_{\mathrm{s}}=\frac{S_{\mathrm{y}}}{S_{0}},
$$

where $S_{y}$ is the area of the hazard zone (exposed to the impact of natural disaster) within the territory under investigation and $S_{0}$ is the total area of the territory. Small-scale estimation of this index is difficult, so corresponding values were calculated on the basis of the close correlation existing between the susceptibility of a territory to snow avalanches and such parameters as absolute height, relative height and landscape type, as proved by Blagovechshenskiy (1991). To determine particular values of the index, both hypsometric and landscape maps of different territories under investigation were used.

\section{Complete social (collective) avalanche risk}

The complete social (collective) avalanche risk of fatal accidents among the people is a function of population vulnerability in time and space, avalanche frequency and population density:

$$
R_{\mathrm{f}}=F d V_{\mathrm{t}} V_{\mathrm{s}}
$$

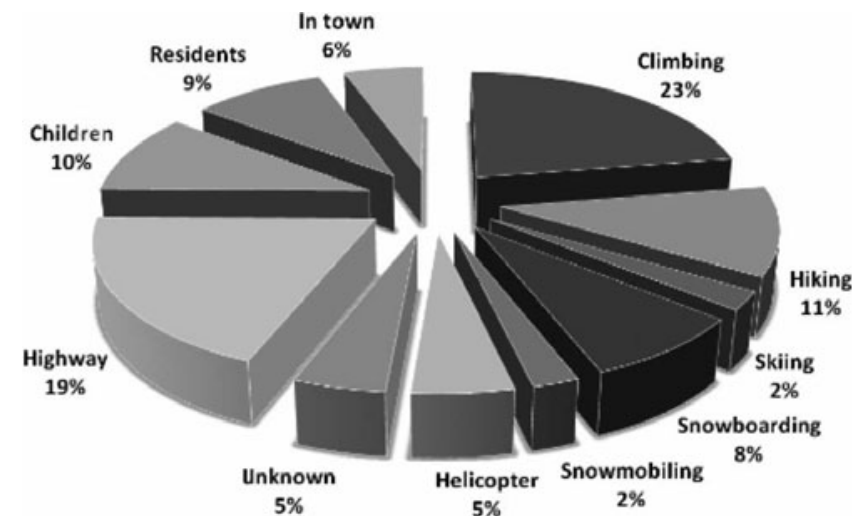

Fig. 3. Avalanche fatalities by activity/location in Russia as a whole for the period 1996-2007.

where $F$ is the average recurrence interval of avalanches for an average size avalanche and $d$ is the density of population in the area under investigation. This index shows the annual number of fatalities resulting from avalanche impact.

\section{Individual avalanche risk}

This is the probability of an avalanche leading to the death of an individual member of a particular group within the territory under investigation during a 1 year period. This index is calculated by dividing the complete social risk by the total population of the given area:

$$
R_{\text {ind }}=\frac{R_{\mathrm{f}}}{P},
$$

where $P$ is the total number of local dwellers.

Following the recommendations of the Russian Ministry of Emergency Situations (Vorobiev, 2005), three types of zones with different levels of individual avalanche risk are distinguished on avalanche risk maps. Values less than $1 \times 10^{-6}$ indicate acceptable-risk areas, where no special avalanche protection measures for the population are needed and new buildings and other constructions can be erected without restriction. Values from $1 \times 10^{-6}$ to $1 \times 10^{-4}$ define the boundaries of admissible-risk areas, where considerable avalanche protection measures for the population must be carried out and the erection of buildings and other constructions is possible only in combination with large-scale avalanche control programs, which may lower individual avalanche risk indices to the acceptable level. Values more than $1 \times 10^{-4}$ characterize unacceptable-risk areas, where no new construction projects are permitted and, for existing systems and developed lands, a whole set of avalanche control measures is compulsory to protect the population and lower the level of risk.

\section{RESULTS AND INTERPRETATION}

Using Equation (3), we estimate the values of complete social (collective) avalanche risk as 26 fatalities for Sakhalin, and 47 fatalities for the northern Caucasus. According to the statistical information available, the corresponding registered annual values for the period 1996-2007 are 1 and 12 fatalities. However, half of the fatalities in the northern Caucasus are composed of tourists, and the data on tourist fatalities are either not collected or are concealed. The final estimates are 


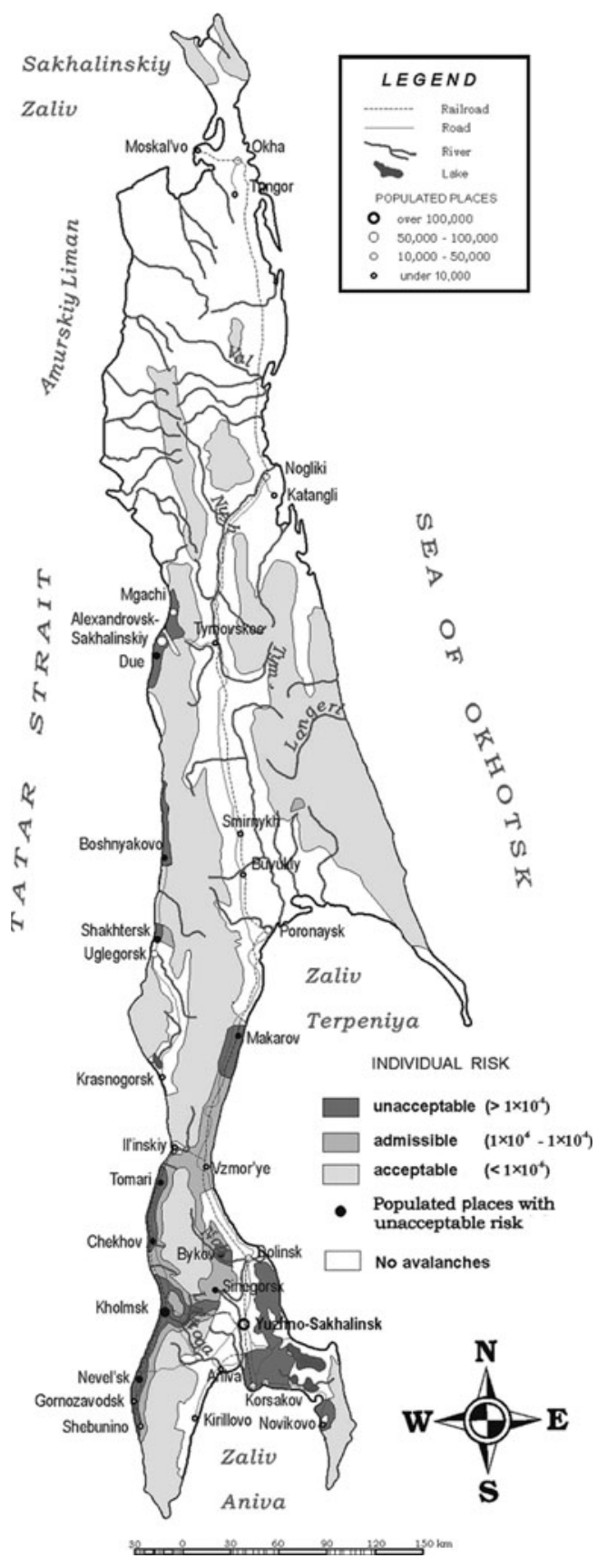

Fig. 4. Individual avalanche risk on Sakhalin island.

considerably larger than the real fatal-accident rate. The probable reasons for these differences are as follows:

for the most part, only short-term records of avalanche catastrophes and victims (including data for the whole years 1996-2007) are available;

substantial changes (relative reduction) in avalanche activity have occurred in most of the investigated areas, and our estimates are based on meteorological information characterizing the avalanche frequency and the length of the avalanche danger period only during the period 1960-90;

the efficiency of the measures implemented to protect people from avalanche impact, which plays a crucial role in reducing the fatal-accident rate in any avalancheprone region, has been underestimated.
Comprehensive analyses and calculations, using Equations (1-4), have resulted in the implementation of individual and collective risk assessments and the compilation of smallscale maps of Sakhalin and the northern Caucasus (Figs 4 and 5). We conclude that the highest values of individual avalanche risk in Sakhalin are typical for areas along the west coast. Although local avalanches are characterized by small volumes, they can cause large numbers of fatalities and considerable economic damage, because a number of thoroughfares, electric power transmission lines and human settlements are situated in the coastal zone under their possible impact. Just in this part of the island, there are several territories with an unacceptable level of individual avalanche risk. In the towns of Kholmsk and Nevel'sk, for example, the values are $1.5 \times 10^{-4}$ and $3 \times 10^{-4}$ respectively. The highest level of individual avalanche risk, $4 \times 10^{-3}$, is observed in the town of Sinegorsk due to an extreme rate of avalanche activity, high population density and the location of many buildings and other constructions within avalanche paths. Relatively high values of individual avalanche risk are also typical for the highway and railroad between YuzhnoSakhalinsk and Kholmsk, which cross the Mitsul'skiy and Yuzhno-Kamyshovy mountain ranges.

Our results show that approximately $85.1 \%$ of the avalanche-prone territory of Sakhalin consists of areas with an acceptable level of individual avalanche risk. Admissible risk applies to areas comprising about $14.8 \%$ of the avalanche-prone territory. Areas with an unacceptable level of individual avalanche risk, concentrated in urbanized zones (e.g. in the vicinity of the towns Kholmsk, Nevel'sk and Tomary), cover only the remaining $0.1 \%$ of the avalancheprone territory.

Major mountain resorts, including Krasnaya Poliana, the Mount Elbrus region and Dombai, densely populated lands in Dagestan, and the trans-Caucasian highway zone, belong to unacceptable-risk areas of the northern Caucasus, which occupy $7 \%$ of the avalanche-prone part of the region, while the values for admissible- and acceptable-risk areas are $52 \%$ and $41 \%$ respectively. These conclusions are illustrated by the map (Fig. 5) showing the sites of some catastrophic avalanche events. Most are located within areas characterized by unacceptable, and few in areas with admissible, levels of individual avalanche risk.

\section{CONCLUSION}

Studies of avalanche processes and events have been conducted in Russia for several decades. Until recently, the basic parameters of the avalanche activity itself, i.e. geophysical characteristics, were mainly considered. The analysis of specfic features of avalanche impact on human society and its mode of life was limited by the registration of disasters that had already occurred and the compilation of an inventory of various systems and structures under threat. Integrated successive appraisal of the avalanche risk assessment undertaken can help mitigate the social and economic consequences of avalanche activity and assist in selecting rational avalanche control measures. The suggested methods of complete social (collective) and individual avalanche risk estimation, using simple and easily obtainable geophysical, social and economic information, allow us to carry out both small- and medium-scale risk evaluation even for insufficiently explored avalanche-prone areas. As the described methods of avalanche risk assessment have been elaborated 


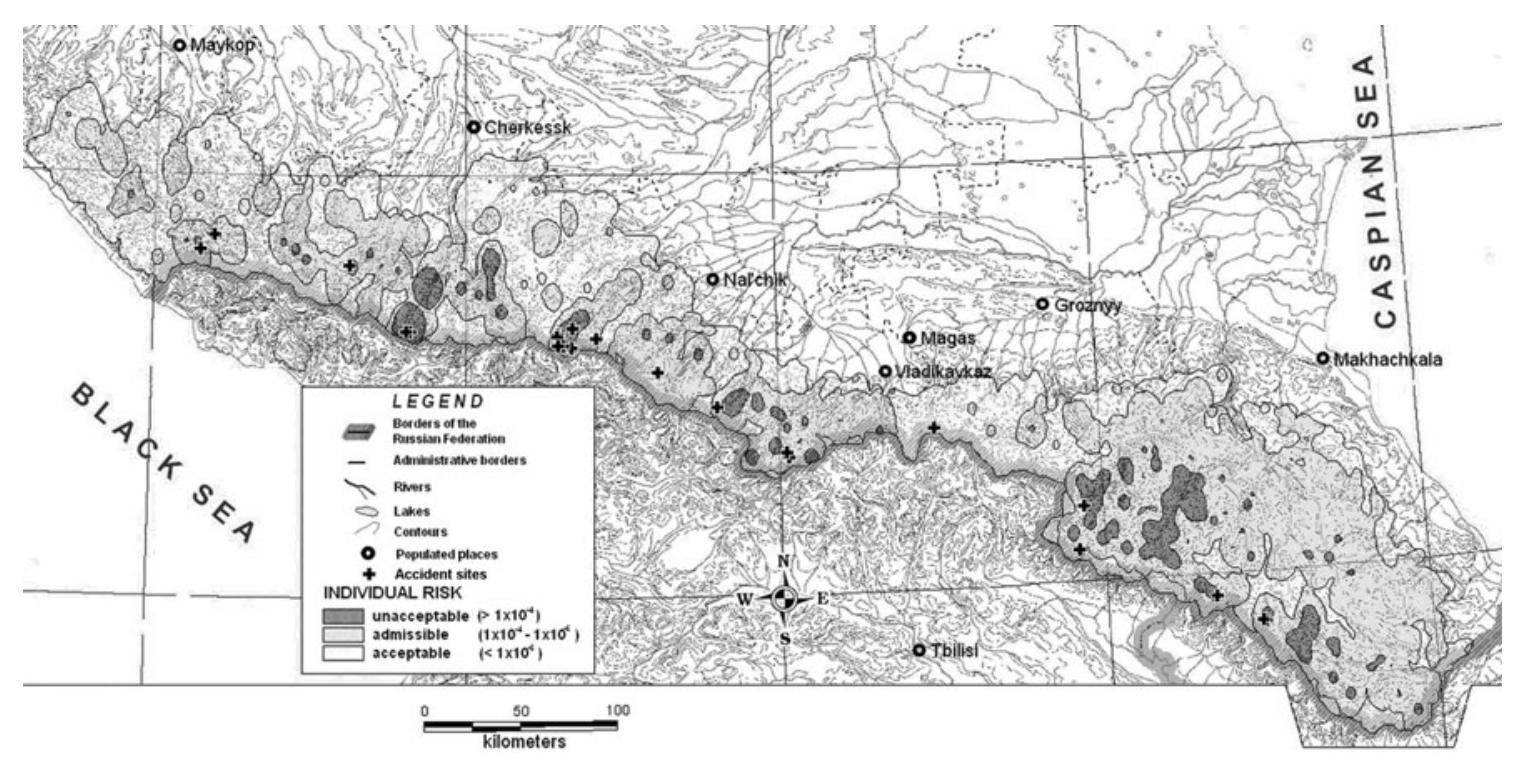

Fig. 5. Individual avalanche risk and the sites of some fatal avalanche accidents in the northern Caucasus in the period 1996-2007.

based on a methodology similar to that applied to karst phenomena and processes research, we believe that such an approach can also be used to study other natural disasters (e.g. debris and slush flows, earthquakes, landslides).

\section{REFERENCES}

Andreev, Yu.B., A.N. Bozhinskiy and T.L. Sidorova. 1997. Metodika kartorafirovania veroyatnogo ushcherba ot lavin i seley [The methodology of mapping of probable damage due to avalanche and mud-flow activity]. Vestn. Mosk. Univ., Ser. 5, Geografija, 5, 67-69. [In Russian.]

Arnalds, T., K. Jónasson and S. Sigurðsson. 2004. Avalanche hazard zoning in Iceland based on individual risk. Ann. Glaciol., 38, 285-290.

Bell, R. and T. Glade. 2004. Quantitative risk analysis for landslides: examples from Bíldudalur, NW Iceland. Natur. Hazards Earth Syst. Sci. (NHESS), 4(1), 117-131.

Blagovechshenskiy, V.P. 1991. Opredeleniye lavinnykh nagruzok [Determination of avalanche loads]. Alma-Ata, Science. [In Russian.]

Bohnenblust, H. and C. Troxler. 1987. Risk analysis - is it a useful tool for the politician in making decisions on avalanche safety? IAHS Publ. 162 (Symposium at Davos 1986 - Avalanche Formation, Movement and Effects), 653-662.

Institut Geografii RAN. 1997. Atlas snezhno-ledovykh resursov mira II [World atlas of snow and ice resources. Vol. 2]. Moscow, Glavnoe Upravlenie Geodezii i Kartografii. [In Russian.]

Jónasson, K., S.T. Sigurðsson and T. Arnalds. 1999. Estimation of avalanche risk. Reykjavík, Veðurstofa Íslands. (Report No. VÍR99001-ÚR01.)

Kazakov, N.A. 2000. Geologicheskiye i landshaftnyie kriterii otsenki lavinnoj i selevoy opasnosti pri stroitel'stve linejnykh sooruzheniy (na primere o. Sakhalin) [Geologic and landscape criteria of avalanche and debris-flow hazard assessment in case of erecting linear constructions (on the example of the island of Sakhalin)]. (PhD thesis, Moscow State Geological Prospecting University.) [In Russian.]

Keiler, M. and 6 others. 2006. Avalanche risk assessment - a multitemporal approach, results from Galtür, Austria. Natur. Hazards Earth Syst. Sci. (NHESS), 6(4), 637-651.
Keylock, C.J., D.M. McClung and M.M. Magnússon. 1999. Avalanche risk mapping by simulation. J. Glaciol., 45(150), 303-314.

Kurbatova, A.S., S.M. Miagkov and A.L. Shniparkov. 1997. Prirodnyy risk dlia gorodov Rossii [Natural risk for cities of Russia]. Moscow, City Ecology Institute. [In Russian.]

Margreth, S., L. Stoffel and C. Wilhelm. 2002. Winter opening of high alpine pass roads: analysis and case studies from the Swiss Alps. In Proceedings of the International Snow Science Workshop, 29 September-4 October 2002, Penticton, British Columbia, Canada. Penticton, B.C., International Snow Science Workshop, 59-66.

Miagkov, S.M. 1995. Geografiya prirodnogo riska [Geography of natural risk]. Moscow, Moscow State University. [In Russian.]

Molotkov, N.M. 1992. Risk prirodnykh opasnostei v gornom turizme [Risk of natural hazards in mountain tourism]. In Melkomasshtabnoe kartografirovanie prirodniykh opasnostei i stikhiiniykh bedstviiy [Small scale mapping of natural hazards and disasters]. Moscow, Moscow State University, 221-232. [In Russian.]

Seliverstov, Yu.G. 1992. Metodika rascheta economicheskogo ushcherba ot lavinnykh zavalov na avtomobil'nykh dorogakh (na primere Kirgizii) [Methodology for estimation of economic damage from avalanche obstructions on the automobile roads (on the example of Kirgizia)]. In Melkomasshtabnoe kartografirovanie prirodniykh opasnostei i stikhiiniykh bedstviiy [Small scale mapping of natural hazards and disasters]. Moscow, Moscow State University, 233-242. [In Russian.]

Vorobiev, Yu.L. 2005. Bezopasnost zhiznedeyatel'nosti (nekotorye aspecty gosudarstvennoy politiki) [Safety mode of living activity (some aspects of public policy)]. Moscow, Russian Ministry of Emergency Situations. [In Russian.]

Wilhelm, C. 1998. Quantitative risk analysis for evaluation of avalanche protection projects. In Hestnes, E., ed. 25 Years of Snow Avalanche Research at NGI. Proceedings of the Anniversary Conference, 12-16 May 1998, Voss, Norway. Oslo, Norwegian Geotechnical Institute, 288-293. (NGI Publication 203.)

Yolkin, V.A. 2004. Regional'naya otsenka karstovoy opasnosti i riska (na primere Respubliki Tatarstan) [Regional assessment of karst hazard and risk (on the example of Republic of Tatarstan]. (PhD thesis, Russian Academy of Sciences Geoecological Institute.)

Zischg, A., S. Fuchs, M. Keiler and J. Stötter. 2005. Temporal variability of damage potential on roads as a conceptual contribution towards a short-term avalanche risk simulation. Natur. Hazards Earth Syst. Sci. (NHESS), 5(2), 225-233. 